\title{
IBRAHIM M. ABU-RABI (1956-2011): A REFLECTION
}

\author{
Ian S. Markham \\ Virginia Theological Seminary, Alexandria, Virginia-USA
}

Abu-Rabi was a child of the world. He was a Palestinian born in Nazareth in 1956; he was educated at Roman Catholic schools on the West Bank. He obtained his Bachelor's degree from Birzeit University in 1980. He then moved to the United States, getting a Masters of Arts degree in political science from the University of Cincinnati in 1982. And then he went to Temple University in Pennsylvania for a further Master's degree in religious studies. He remained at Temple University for his PhD studies. He obtained his doctorate in Islamic Studies in 1987 where he worked with Dr. Leonard Swidler. He held both Israeli and US passports; he worked with Christians, Jews, and Muslims. He spoke a multitude of languages - Arabic, English, Hebrew, Urdu, and, at the time of his death, was working on Turkish. Among his many honors, he was appointed in 2006 the Senior Fulbright Scholar in Singapore and Indonesia at the Institute of Defence and Strategic Studies at Nanyang Technological University in Singapore.

His academic career started with an appointment at Virginia Commonwealth University, followed by the University of Texas at Austin. Upon his death he was the holder of the Edmonton Council of Muslim Communities Chair in Islamic Studies, at the University of Alberta. He was the first holder of this chair; his task in this University was to build up its reputation as a center of Islamic Studies. He did this work well, building partnerships around the world. A skill he had learned at Hartford Seminary in Connecticut. 
Hartford Seminary was an intriguing school. It was first and foremost a Christian seminary, with a United Church of Christ foundation. He was always present at the weekly Seminary chapel, often being the worship leader. He was a committed Muslim; this was the primary prism through which he saw the world. And it was out of this deep sense of commitment to Islam that he worked with Christians.

In term of scholarship, his first substantial book was the Intellectual Origins of Islamic Resurgence in the Modern Arab World (Albany: State University of New York, 1996). In many ways this was a book ahead of its time. He was anticipating the Islamist movements that were to become so significant in the subsequent decade. Perhaps his finest book was his Contemporary Arab Thought: Studies in post1967 Arab Intellectual History (London: Pluto Press, 2004). With his proficiency in languages, he was accessing the primary sources in ways that many Western commentators on Islam were not able to do so. In this book, the breath of his reading was remarkable and the connections in terms of trends were striking.

He approached questions primarily as a political theorist. His analysis had an almost Marxist sensitivity. He understood the challenges facing the Middle East to have their roots in the colonialism of the early $20^{\text {th }}$ century. The economic factors were primary. However, Abu-Rabi was always aware of the complexity of the many factors that created a culture. He rarely generalized from one setting to another. So, for example, he often stressed the differences between Islamic political culture in the Middle East with that found elsewhere in the world.

Indeed his interest in non-Middle East forms of Islam is part of his enduring legacy. He knew countries like Indonesia, Pakistan, and Turkey extremely well. It was his passion for introducing to the world the complexity of Islam that led to much of his work as an editor of books. For example, he was responsible for the initial collections of essays in English on the Turkish Islamic thinker Bediuzzaman Sa ${ }^{1} \bar{d}$ Nūrsī. At a time when the scholarly world was still largely unaware of his significance, Abu-Rabi edited the volumes that made scholars of Islam aware of Nūrsī.

Perhaps the aspect of his work, he was most proud of, was his responsibility as co-editor of the prestigious journal The Muslim World. He took pride in creating themed issues (some looking at $\mathrm{Pa}$ - 
kistan, others at a particular Islamic thinker). The quality of the journal (along with its subscribers) grew significantly in this period. It was this interest in quality that led him to support and serve many conferences and journals. It was in this spirit that he served on the editorial board of Ilahiyat Studies.

As a friend, he was loyal and committed. With his wife Fatima, he opened his home often and generously. He had a delightful sense of humor and a strong sense of hospitality. He loved his children. His premature death leaves an irreplaceable gap for so many of us.

Yet we are grateful for the service and insight he offered the academy, scholarship, and his many students. As a result of working with Abu-Rabi, many of us saw the world differently. This was his gift to us all. 